\title{
NADSAT - THE LANGUAGE OF VIOLENCE: FROM NOVEL TO FILM
}

\author{
Israel A. C. Noletto* \\ Instituto Federal de Educação, Ciência e Tecnologia do Piauí \\ São Raimundo Nonato, Piauí, BR \\ Margareth Torres de Alencar Costa ${ }^{* *}$ \\ Universidade Estadual do Piauí \\ Teresina, Piauí, BR
}

\begin{abstract}
Nadsat, an artificial language constructed by Anthony Burgess, is used in his novel, apparently, as means both of immersion, alienation and repulsion of the reader. Kubrick's filmic adaption of A Clockwork Orange recognizes the paramount role of Nadsat, and gives life to it as a spoken language through the lines of Alex and his droogs in his homonymous production. The aim of the present article is thus to examine the author's artificial language, its occurrences in the novel as well as in the filmic adaptation following the contributions of Gualda (2010) and Hutchings (1991) to film studies, while tracing the glossopoeia's meanings and effects on the audience, and how both the author and director seem to manipulate the implications of reception theory as formulated by Wolfgang Iser (1978). The questions answered by this article are whether the role played by Nadsat in the novel corresponds to that played in the film; and what the implications of Iser's reception theory in the novel and the film are. The results will show that without an understanding of Nadsat the reader/viewer will not be able to fill the gaps of interpretation left by Burgess and Kubrick.
\end{abstract}

Keywords: Nadsat; A Clockwork Orange; Novel; Film; Reception Theory

\section{Introduction}

There was me, that is Alex, and my three droogs, that is Pete, Georgie and Dim and we sat in the Korova milkbar trying to make up our rassoodocks what to do with the evening. The Korova Milk Bar sold milkplus, milk plus vellocet or synthemesc or drencrom which is what we were drinking. This would sharpen you up and make you ready for a bit of the old ultraviolence. [Italics are ours] (Kubrick 2)

With those words, almost identical to the novel's introductory paragraph, Kubrick opens the first scene of his acclaimed adaptation. Before that, however, an intriguing change of screen colours is presented. As the music starts, a completely red screen appears, possibly a simple visual reference to the violence and horrible scenes that follow. The red screen continues for a few seconds, and then production credits are shown, while the screen turns blue. After that, a new red screen comes up. The first appearance of Alex, the protagonist, begins in close-up of his eyes, zooming out to show the Korova milkbar, in which the 04 (four) droogs are drinking moloko. The first scene as well as the first paragraph in the novel is when the audience is introduced to the artificial language ${ }^{1}$ Nadsat, as shown in the quotation aforementioned that can be read in the

\footnotetext{
* Israel Noletto currently teaches English as a Foreign Language at IFPI (Piauí Federal Institute) and is taking his Master's Degree in Literary Theory at UFPI (Piauí Federal University), and has a degree in English from UESPI (Piauí State University/ 2009). His email address is israelnoletto@ifpi.edu.br

** Margareth Torres de Alencar Costa teaches Spanish as a foreign language at UESPI (Piauí State University) and Literary Theory at UFPI (Piauí Federal University). She has a Doctorate in Literature from UFPE (Pernambuco Federal University/2013), a Master of Arts also in Literature from UFPE (Pernambuco Federal University/2002), and a degree in English and in Spanish from UESPI (Piauí State University/ 1992 and 2012 respectively). Her email address is margazinha2004@yahoo.com.br
} 
light of Iser's theory (7), which states that the text itself is a "prefiguration of reception", bearing a potential effect whose structures set in course an assimilation and control it up to some point preparing the reader for the exercise to come.

The film was produced in 1971 and prohibited in many countries, because of the many violent and brutal scenes. In Brazil, for instance, it was only uncensored in 1978. Based on the homonymous novel written by Anthony Burgess, it is acclaimed by many as a perfect film. Everything in it fits accordingly - scenography, casting, photography, costume design and music - to create an apparently distant environment, a chaotic and dark world in which Alex, a British youngster leads a delinquent group of adolescents who go out in the night chasing and beating up people under the effect of hallucinogens, always in a mood of sarcasm and reckless entertainment. The aim of the present article is thus to examine the author's artificial language, its occurrences in the novel as well as in the filmic adaptation following the contributions of Gualda (2010) and Hutchings (1991) to film studies, while tracing the glossopoeia's meanings and effects on the audience, and how both the author and director seem to manipulate the implications of the reception theory as formulated by Wolfgang Iser (1978). The questions answered by this article are whether the role played by Nadsat in the novel corresponds to that played in the film; and what the implications of Iser's reception theory in the novel and the film are. The results will show that without an understanding of Nadsat the reader/viewer will not be able to fill the gaps of interpretation left by Burgess and Kubrick. This line of thought agrees with Iser (10) who states that the literary text derives from an author's reaction to the world and becomes reality as it brings forth to the present world a perspective that does not exist in it: subjectivity.

The glossopoeia ${ }^{2}$ through which Alex communicates to the audience is a mixture of English and Russian as well as some bits of the Cockney dialect. But why did Burgess pick Russian, specifically? asks Evans (409). If the goal were just to render a foreign touch to the teen argot, would not French or Arabic suffice? Or would not, indeed, any other language? The use of the language from the Kremlin may suggest a fusion of two dominant politic-economic systems of the time in which Burgess wrote his novel: communism and capitalism. The fact that the book was first published in the United Kingdom, an openly capitalist and anti-communist country, makes it evident that the sounds of Nadsat were meant to unconsciously and subliminally generate alienation in the reader, and later in the cinema audience, because of the association with the communist country (Vadillo 4). Just like in the novel, in the film, Alex introduces his world and Nadsat little by little, but as the public goes further in the story and grows more familiar with the glossopoeia, a bond is made with the character and the reader as much so as to overlook his lack of morality and ethics in Alex's pitiless actions.

And that is possibly the author's intention, the same that happens to the protagonist while exposed to the so-called Ludovico technique. The feeling created is that of a strange person from maybe a gang who has a unique and hard-to-get slang, someone the interlocutor has to struggle to understand because of an unusual and exotic vocabulary, but for which the context can most of the times provide the meaning, as demonstrated below:

\begin{abstract}
There were three devotchkas sitting at the counter altogether, but there were four of us malchicks and it was usually like one for all and all for one. These sharps were dressed in the heighth [sic] of fashion too, with purple and green and orange wigs on their gullivers [...] They had long black very straight dresses, and on the groody part of them they had little badges [...] (Burgess 4) [Italics are ours]
\end{abstract}

As the context suggests, the words 'devotchkas' and 'sharps' probably mean 'girls' (a deeper analysis will follow). That can be inferred from the fact they wore dresses. Whilst 'malchicks' is likely the equivalent to 'boys', since they call themselves 'malchicks' as opposed to 'devotchkas'. Now, 'gullivers' obviously means 'heads', for the 'sharps', or the girls, are said to be wearing wigs on their 'gullivers'. Groody sounds much like the Russian груд [grud]. Iser's theory explains the strangeness that the text causes on its reader if one considers the way in which the texts are acquired and the manner in which 
the structures are elaborated in the text for those who receive it. Considering, furthermore, the effort that must be performed by the reader in order to understand such a different language, or conlang, it is only natural to agree with Iser (1978) concerning the struggle in which the reader is involved; the comprehension thereof is not restricted to images or significations, but also in the effect of the text in its reception.

\section{Nadsat - An Overview}

The word Nadsat originates from the Russian

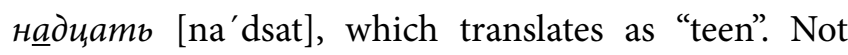
exactly a real language, with a fully independent grammar and extensive vocabulary (like the examples in Tolkien's sagas), it is the slang used by the juvenile delinquent antiheroes of A Clockwork Orange; however, this article will still refer to Nadsat as a language anyway, from time to time, because this is what most writers and theorists do. The words Burgess invented, generally nouns and adjectives, are mostly loans from Slavic roots, in an Anglicized form, usually characterizing crimes and body parts; there are occasionally an odd German word or two, as well (Evans 406). In his memoir 'You've had your time', the author explains that the youths' vocabulary had been designed as "mixture of Russian and demotic English, seasoned with rhyming slang and the gipsy's bolo" (Conley; Cain 28). Following that line of thinking, words like bitva (fight) and bolnoy (sick) are found, transparent to anyone who knows Russian.

Not all the words coined by Burgess come from Anglicized Russian roots, though. Along with that, he also uses English roots or proper names as seen on page 04 (four) of the book, when Alex uses the word Gulliver to refer to heads, the body part of the girls at whom he was staring (Vadillo 9).

Invented words like appypolly loggy (apology), charlie (chaplain or priest) and pretty polly (money) demonstrate that Burgess also used rhyming slang, like that found in the Cockney dialect, to form a few of his neologisms. Various inventions, however, are neither of Russian origin nor of Cockney influence. The author also created some expressions from scratch. That is the case of pop-disk (pop-music disc), pee (father), mounch (snack) and in-out-in-out (sex). A particularly interesting case is the word for man. The Nadsat word for man (or any general person, human) is orange from Malay orang. That is obviously related to the meaning behind the novel's title A Clockwork Orange, which in turn is meant to signify a clockwork man, someone who has been programmed by society to show certain behaviour, just like what happened to Alex after the brainwashing process, in which he was "trained" to repulse the once beloved violence and sex, similarly to a clockwork toy that can be used totally out of a child's free will. Orange may also be a reference to the English word "orangutan" (from a similar etymology), an orange primate frequently used by scientists in behaviouristic studies. This idea is well supported by the Chaplain's words to Alex, while commenting on Alex's curiosity about the Ludovico treatment: “[...] The question is whether such a technique can really make a man good. Goodness comes from within, 6655321. Goodness is something chosen. When man cannot choose, he ceases to be a man." (Burgess 63). Again, in other words, he becomes a mechanised, programmed, a 'clockwork man'.

As for the syntax, Nadsat tends to resemble more archaic English, or even Shakespearean: "It was Will the English who like said" (Burgess 46). Other instance of such resemblance is found in: "How art thou, thou globby bottle of cheap stinking chip-oil? Come and get one in the yarbles, if you have any yarbles, you eunuch jelly, thou" (Burgess 16); "Never fear. If fear thou hast in thy heart, O brother, pray banish it forthwith" (Burgess 18). That artificial formality, a sort of misplaced language courtliness, say, is possibly a reference to the moral immaturity of Nadsat users.

Hence, some of the words invented by Burgess are clearly meant to make a moral point. Horrorshow, for instance, appears to be transparent in meaning, horror plus show or show of horrors. Still, indeed, it is more probably a corruption of xорошо [xэro' $\mathrm{jo}$ ], usually transliterated as kharashó, the Russian word for 'good', which is by the way the attributed meaning of horrorshow. Slang can frequently invert meanings so that a word for good is used as bad and vice versa. Although to call something horrorshow is a favourable 
judgment, what Alex describes as horrorshow is always associated with violence.

The Ludovico treatment, a brainwashing process to which Alex is subjected by psychologists and politicians, is evidently intended as a mimesis of the real "brainwashing" that is taking place in the novel, that is, the disorientation created by the narrative's use of Nadsat. "The reader would be brainwashed into learning minimal Russian," and "The novel was to be an exercise in linguistic programming", Burgess asserts, as recounted by Conley and Cain. That shows just how subversive the novel was envisioned to be: teaching the British and American audience some Russian within the Cold War itself (Conley; Cain 29).

The ideas and intentions behind the use of Nadsat in the narrative can, thus, be summarised by the following quotation taken from Conley and Cain's Encyclopedia of Fictional and Fantastic Languages.

Compared with the "harmless" and altogether bourgeois "word game" of socially welladjusted and professionalized adults, nadsat is, for all its glorification of violence and misogyny, perversely poetic, and for this reason it is not surprising that it is frequently mimicked and burlesqued by readers and viewers of $A$ Clockwork Orange. (Conley; Cain 29).

\section{Nadsat, from novel to film}

Primarily, a great film generally consists of a great story. The great cinematographic productions, since their origins, have alternately been adaptations and novelties. Scriptwriters would not be capable of producing hundreds of unedited situations every year; therefore, they resort to literary masterpieces or successful books. The frequency in which literary pieces are adapted onto the screen makes it a very debateable area concerning the quality and the "fidelity" of such adaptations (Gualda 214).

To Gualda, no matter how faithful the adapter tries to be to the original story, he will always have to suppress certain episodes, or to amplify others that are more interesting to the adapter's purposes, since total fidelity is made impossible by the different means of expressions in the novel and in the film (Gualda 215). Upholding that premise, Bluestone (219) emphasizes that adaptation is a process based on the fact that changes are inevitable when the linguistic field is abandoned for the visual one.

It could not be different in the case of A Clockwork Orange. It is largely known that Anthony Burgess has long been dissatisfied with the text of his novel that was published in the United States, which omitted the novel's final chapter and added an unauthorized and unnecessary glossary (or so in the author's judgment). Stanley Kubrick wrote the screenplay for the filmic adaptation based just on that American edition of the novel and that, again, displeased Burgess very much (Hutchings 36).

Although the portrayal of the book's more violent scenes has ever been a crucial matter in every adaptation of Burgess's novel, an on-screen enactment of a beating, murder, or rape is essentially different or more shocking than its novelistic description in language. Particularly, Alex's "Nadsat" argot might have conveyed certain distancing effect in both the book and the film, since the words in the slang do not transmit the same force as the words in the audience's own language (Hutchings 38). Much was changed concerning that question in the filmic adaptation of the book. For instance, Kubrick's rendition of the scene exploits its violence and voyeurism (like in its use of close-ups as Alex shreds the woman's red jumpsuit before the rape), but it is far less detailed than in the novel:

'Pardon, madam, most sorry to disturb you, but my friend and me were out for a walk, and my friend has taken bad all of a sudden with a very troublesome turn, and he is out there on the road dead out and groaning. Would you have the goodness to let me use your telephone to telephone for an ambulance?'

'We haven't a telephone', said this devotchka. 'I'm sorry, but we haven't. You'll have to go somewhere else.' From inside this malenky cottage I could slooshy the clack clack [...] (BURGESS 17) [Italics are ours].

For the on-screen scene of Kubrick's film, the dialogues were reduced significantly and the 
demonstrations of violence were made more explicit, but the sort of language used (formal English in the beginning and Nadsat in the end) was kept nearly unchanged. Alex enters the house singing a song, spanking the couple along with his droogs and finishes the scene with the sentences: "Viddy well, my little Brother. Viddy well." (Kubrick, 1971, p. 6). A clear and objective description of the filmic vision of the rape narration is provided by McQueen who, curiously, utters his premises using some Nadsat words:

In the first scene, we are explicitly told to viddy, sharing the perspective of Mr Alexander. The camera then moves from his face to that of his wife as she is molested. In the second scene, we share the gaze with Alex, one who viddies instinctively. In both scenes, the camera is at times shaky, capturing the violence in an exploratory and declarative fashion, but also uncertain in its framing. The first scene is brief, suggestive of a simultaneous immersion and repulsion. This is a forced relation of one who does not viddy instinctively, namely Alexander or the cinematic spectator who, via editing assumes an uncomfortable perceptual sympathy. (McQueen 236)

Indeed, if there is one thing that Kubrick did not change much, it was the Nadsat slang. He did not modify the words at all, although he suppressed some of their occurrences. It is immediately recognizable and unique, a distinctive "voice-print", as pointed out by Hutchings (40). Ironical, therefore, is the aforementioned "alienation effect" that Nadsat can cause on the audience. Whether it was intentional and whether that was the effect the author intended will be dealt with in the next topic following the point of view of Iser's aforementioned Reception Theory.

\section{Iser's reception theory reflected on Burgess's and Kubrick's use thereof}

"Meaning is not an object to be described, but an effect to be experienced" (Iser 10). This short passage synthesizes how Wolfgang Iser understands reception theory, which, according to what was conceived by him, states that the interpretation attributed to a text, the place it is granted in the history of science, comes about in its reception, that is: through the sundry meanings that the reader, or else in the case of the film, the viewer, from different horizons of experience and expectations is able to attribute to it. In such a process, each preceding work becomes a conditioning factor of each subsequent reader/viewer (Grumbrecht 1007).

In that perspective, the author and the reader must share certain number of the conventions present in the text; and the employment of those conventions must be directed by accepted procedures. It is possible to deduce, therefore, that the good old question as to what a poem, drama or novel really means has to be replaced by that question as to what happens to the reader when they bring fictional texts into life, through their reading (Grumbrecht 993). In his The Act of Reading, Wolfgang Iser arguments that:

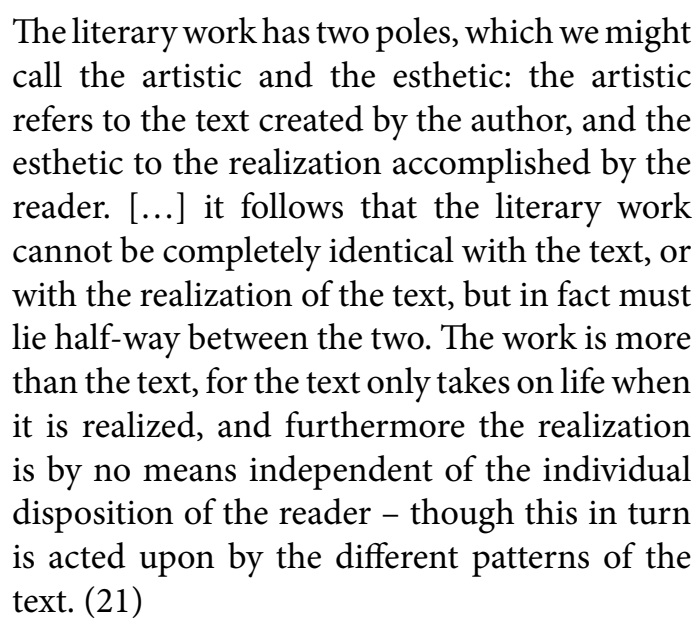

Accordingly, it is safe to say that there is an organization of signifiers in literature that designate instructions for the production of the signified rather than a signified object (Iser 65). For that matter, the presence of Nadsat plays an important role in the way both the novel and the film are received by the audience, in such a way that the author doses the amount of information readily available to the reader, and, in a smaller scale, as well in the film. The strangeness and unfamiliarity of the glossopoeia may prompt the reader/ viewer's curiosity at the beginning of the novel and the film as to learn what the narrator, Alex, is really saying. The number of different words, although inserted in an English "speaking" text, is enough to complicate 
the audience's understanding, making necessary that the reader/viewer pays more attention. Corroborating Iser (1978), it is plausible to verify that the effect and reception are in consonance with the update of the literary text and that of the filmic text. In so far as the receptor of the literary and filmic texts enters this universe, the glossopoeia becomes part of the receptor's comprehension and he/she can enjoy the text and from there on will be able to feel the 'strangeness' that will make him/her continue stuck in the webs of the text.

For someone who only speaks English or does not speak any Slavic language (the paradigmatic reader/viewer considered for this article), unaccompanied by a Nadsat glossary (just the way intended by Burgess) 200 (two hundred) "foreign" words seem to "have fallen from the sky ready-made", using Derrida’s expression (McQueen 229). It can be said that Burgess intended such a reading task, that is, to internalise the artificial language, just by reading further (practice), since checking the glossary would be tedious; Bakhtin once said, "it is not, after all, out of a dictionary that the speaker gets his words!" (293). To what extent are readers successful in getting the meaning of Burgess's neologisms, McQueen (229) presents a brief study, which concluded that, in average, English-speaking readers were able to get right 76 (seventy-six) percent of the Nadsat words, by reading for meaning; it must be noted that such degree of accuracy is logically due to the simultaneous presence of both English and Nadsat, which offers a partial linguistic recognition, but with sufficient alternativity to render the reception of defamiliarization. At this point, it is necessary to resort to Iser in order to elucidate the reception and the effect of the reading and the film. The text presents itself as a process. The text cannot be attached either to the author's reaction to the world or to the acts of selection and combination, or to the processes of meaning formation that occur in the elaboration, or even to the aesthetic experiences. On the contrary, the text is an integral process that comprehends both the author's reaction to the world and the reader's experience (Iser 69).

The attempt to master Nadsat results in immersion, and flow is established. Simultaneously, however, the period between learning and understanding the glossopoeia causes certain alienation on the reader in the logic that the brutality in the Nadsat narrative, the actual unhuman and grotesque way in which Alex and his droogs view their violent and shocking acts is not exposed to the reader and, consequently, the reader is, say, still protected from the whole cruel "reality" (Ravyse 5). This, of course, does not entirely apply to the film, since the major language used to communicate and translate all the crudity and brutality so peculiar to the main characters is not only verbal, but dominantly visual. The initial scenes that show the old veteran being beaten or the young girl being group-raped cannot be disguised by the use of an unknown language. Nonetheless, the sentiment of pleasure and exaltation of violence plus cruelty as well as the total lack of pity or regret are better represented by the use of Nadsat and better perceived by the viewers once they realize the meanings of Burgess's neologisms; accordingly, if they never come to master the language, there will always be a missing message still to be caught by the spectator.

The behaviouristic technique and the treatment that Alex receives match one of Iser's assumptions, which questions, among other things, to what extent the literary text lets itself be acquired as a realization; and to what point the elaborations provoked by the text are previously structured by it. Such questionings are quintessential to the aesthetic of effect; and through them, the interaction between text and context, as much as between text and reader, constitutes the object of attention (Iser 13).

Thus, the literary and filmic texts caused in the public a race to the bookshops and cinemas in order to prove the commentaries and critiques, by the time of the publication of the written form and the exhibition of the film based on the novel. Nowadays, both the novel and film are still capable of causing such an effect on readers/viewers proving correct what Iser stated about his effect theory being anchored on the text, while the theory of reception is anchored on the historical judgements of its readers/viewers.

\section{Conclusion}

It has been said that $A$ Clockwork Orange is a challenge to judges of taste: some critics' complained in 
the debate that the film did not faithfully follow Burgess's novel, but critics also praised its artful adaptation of the novel, its innovative set design and actors' skilled performance. Among readers and viewers the same applies. The public is divided into those who see it as a visionary masterpiece dystopia and those who see it as an incitement to crime and violence with a shocking lack of moral values.

Like many other instances of literary artificial languages, Burgess's Nadsat is not mere allegory. It constitutes a part of the plot of paramount importance. The author seems to be playing with ordinary speech conventions, as if he were testing the audience's ability to read, similar to those quips in which letters are replaced or swap positions. Reading the English-Nadsat text is also analogous to reading Shakespeare, which requires unnatural familiarity with old-fashioned vocabulary and expressions. Furthermore, the political message embedded in Burgess's linguistic fabrication is not to be ignored. The artificial Russian-like argot along with the whole generalized violence and crime situation in Britain do as well demonstrate the author's view of what the outcome could have been, had communism spread all over Europe, or it could also represent his views on the audiences' opinions.

In the specific register of filmic productions, the viewer is even more immersed in the language than the reader, both by hearing and confronting it at an intersubjective level. At the same time, the viewer has less time to make meaning out of Nadsat. When it comes to films, the presence of a marking artificial language tends to be related to a high degree of acceptation in the public. That is the case of many of the recent blockbusters: The Lord of the Rings, Star Trek and Avatar. In fact, the importance of a glossopoeia in the plot should not be disregarded.

As demonstrated throughout this article, Nadsat follows an "agenda", a fixed objective of promoting the reader's immersion. As they (viewer/reader) seek to grasp the meanings of the foreign words and succeed, that results in the reader's sympathy, while also alienating them from the cruelty, violence and lack of morals. Alex imposes a sense of brotherhood unto the readers, whilst he is imprisoned and keeps using
Nadsat, although no one there, but the reader or the viewer, understands him. At this point the so-called immersion and alienation reach their maximum level. Kubrick realized the relevance of keeping the argot in the filmic adaptation, even if that could imply a certain degree of initial rejection by the public. And as it turned out, the same approximation phenomenon could be observed in the filmic adaptation.

In that sense, if the readers/viewers do not fully understand Nadsat, they will not be able to fill the gaps of interpretation left by the author/director as Iser theorized. Accordingly, a widely known phrase uttered by renowned Canadian Philosopher Marshall McLuhan (1964) can effusively describe what usually occurs in the beautiful relationship between glossopoesis and literature: "the medium is the message".

\section{Notes}

1. Artificial languages have been used for enrichment of plots in Literature and Cinema for quite a long time. So is the case of Gulliver's Travels by Jonathan Swift (1726), Time Machine by H.G Wells (1895), amongst many others in written texts, besides filmic productions like Ridley Scott's Blade Runner (1986) and James Cameron's Avatar (2009).

2. Glossopoeia (coined by J.R.R. Tolkien) is a Greek word that is compounded by the two words glôssa (language) + poiesis (creation), and describes the artificial languages, those tongues invented by particular authors, called glossopoeists, for various reasons. That term also gave birth to the form glossopoesis. An alternative term also currently in use is conlang, an acronym of Constructed Language.

\section{References}

Bakhtin, M. M. The Dialogic Imagination: Four Essays. Austin: Ed. Michael Holquist, 1981.

Bluestone, George. Novels into Film. Berkeley, University of California Press, 1973.

Burgess, Anthony. A Clockwork Orange. London: Penguin, 1962.

Conley, Tim and Stephen Cain. Encyclopedia of Fictional and Fantastic Languages. Westport: Greenwood Press, 2006.

Evans, Robert O. "Nadsat: The Argot and its Implications in Anthony Burgess' A Clockwork Orange". Indianapolis, Indiana University Press. Journal of Modern Literature 1.3 (March 1971): 406-410. 
Grumbrecht, Hans Ulrich. A teoria do efeito estético de Wolfgang Iser. Teoria da literatura em suas fontes - vol. 2. Rio de Janeiro: Editora Civilização Brasileira, 2002. 989-1014.

Gualda, Linda Catarina. "Literatura e Cinema: Elo e Confronto”. São Paulo. Matrizes 3.2 (jan./jul 2010): 201-220.

Hutchings, William. "What's It Going To Be Then, Eh?': The Stage Odyssey of Anthony Burgess's A Clockwork Orange". University of Toronto Press. Modern Drama 34.1 (Spring, 1991): 35-48.

Iser, Wolfgang. The Act of Reading: A Theory of Aesthetic Response. Baltimore: Johns Hopkins University Press, 1978.

Kubrick, Stanley. A Clockwork Orange Screenplay. New York: Warner Bros., 1971.

McQueen, Sean. "Adapting to Language - Anthony Burgess's and Stanley Kubrick's A Clockwork Orange". Liverpool: Liverpool University Press. Science Fiction Film and Television 5.2 (2012): 221-241.

Ravyse, Nathasha E. "Nadsat: The oscilation between reader immersion and repulsion". Meyerton: Northwest University. Literator 35.433 (2013): 1-5.

Vadillo, Aída Gámez. La lengua artificial Nadsat de A Clockwork Orange como problema de traducción. Barcelona: Universitat Autònoma de Barcelona, 2015.

Recebido em: 15/07/2016

Aceito em: 10/11/2016 